Swarthmore College

Works

$1-1-1980$

\title{
The State As Banker And Entrepreneur: The Last-Resort Character Of The Mexican States Economic Intervention, 1917-76
}

D. C. Bennett

Kenneth Evan Sharpe

Swarthmore College, ksharpe1@swarthmore.edu

Follow this and additional works at: https://works.swarthmore.edu/fac-poli-sci

Part of the Political Science Commons

Let us know how access to these works benefits you

\section{Recommended Citation}

D. C. Bennett and Kenneth Evan Sharpe. (1980). "The State As Banker And Entrepreneur: The Last-Resort Character Of The Mexican States Economic Intervention, 1917-76". Comparative Politics. Volume 12, Issue 2. 165-189. DOI: $10.2307 / 421700$

https://works.swarthmore.edu/fac-poli-sci/70

This work is brought to you for free by Swarthmore College Libraries' Works. It has been accepted for inclusion in Political Science Faculty Works by an authorized administrator of Works. For more information, please contact myworks@swarthmore.edu. 


\section{Comparative Politics}

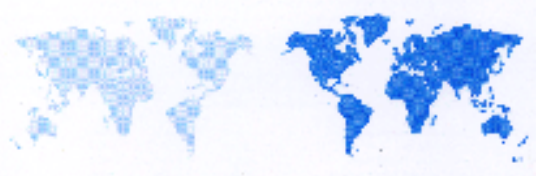

The State as Banker and Entrepreneur: The Last-Resort Character of the Mexican State's Economic Intervention, 1917-76

Author(s): Douglas Bennett and Kenneth Sharpe

Source: Comparative Politics, Vol. 12, No. 2 (Jan., 1980), pp. 165-189

Published by: Comparative Politics, Ph.D. Programs in Political Science, City University of New York

Stable URL: http://www.jstor.org/stable/421700

Accessed: 24-08-2017 21:04 UTC

JSTOR is a not-for-profit service that helps scholars, researchers, and students discover, use, and build upon a wide range of content in a trusted digital archive. We use information technology and tools to increase productivity and facilitate new forms of scholarship. For more information about JSTOR, please contact support@jstor.org.

Your use of the JSTOR archive indicates your acceptance of the Terms \& Conditions of Use, available at http://about.jstor.org/terms

Comparative Politics, Ph.D. Programs in Political Science, City University of New York is collaborating with JSTOR to digitize, preserve and extend access to Comparative Politics 


\title{
The State as Banker and Entrepreneur
}

\author{
The Last-Resort Character of the Mexican State's \\ Economic Intervention, 1917-76
}

\section{Douglas Bennett and Kenneth Sharpe*}

There is a growing body of evidence to demonstrate that the Mexican state that was consolidated in the wake of the Mexican Revolution deliberately created and has continued to nurture a national bourgeoisie which has been a major force in the spectacular economic growth (the "Mexican miracle") of the past four decades, growth that has had little or no benefit for-indeed some argue was built on the backs of - the Mexican lower classes. ${ }^{1}$ And yet, paradoxically, the capitalists that have so benefited rarely view the activities of the Mexican state with more than suspicion, and often portray it as their principal enemy - or perhaps not so surprisingly. Hardly limiting itself to mere infrastructure investments or the provision of investment incentives, the Mexican state has itself emerged as the major banker and entrepreneur in the economy. Its own enterprises have preempted private-sector savings to finance public investment; they have closed off opportunities for private investment; and they enjoy special advantages in sectors where public and private forms compete. Even in comparison with other major Latin American countries, the Mexican state has been atypically and forcefully interventionist in its national economy, particularly with regard to the scope of its involvement in the manufacturing sector. ${ }^{2}$

These two seemingly opposed views of the Mexican state are both factually accurate and reconcilable under the following thesis: Following on the Revolution, the Mexican state came to take on the role of making capitalism work for Mexico, and, in the context of Mexico's being a dependent, late-starting industrializer, this task required, for any degree of success, both major restrictions on the demands of the lower classes and the forceful entry of the state into areas of the economy where the private sector was unwilling or unable to enter, or had entered and failed. The central question of this article addresses part of this thesis: Why has the state emerged as the major banker and entrepreneur in Mexico's economy? ${ }^{3}$ 


\section{Gerschenkron: The State and Requisites of Late Industrialization}

Alexander Gerschenkron's historical researches provide the most insightful starting point for an explanation of state involvement in an industrializing economy. Diverging from the thesis that developing countries travel the same road towards industrialization as more developed ones, only trailing them by some decades, Gerschenkron argues that the industrialization process in the more backward countries requires (among other things) "the application of institutional instruments for which there was little or no counterpart in an established, industrial country." 4 Thus, where capital formation was accomplished in Great Britain through the exertions of individual capitalists, later industrializers (such as France and Germany) required investment banks for the same purpose, and those embarking still later (such as Russia) needed the still more powerful institutional means of the state itself-its taxation powers-to generate the needed investment capital.

Gerschenkron focused his attention on industrialization in Europe, but, in the dependent context of Latin American countries such as Mexico, Argentina, Brazil, and Chile, the dynamics of late, late industrialization have been somewhat different. In these countries, industrialization initially focused not on producer goods, but rather on formerly imported consumer goods through a process of import-substitution originally forced on these countries by depressions and wars in the developed capitalist world. ${ }^{5}$ Even more than for the late industrializers of Europe, this late, late industrialization has set certain problems for these Latin American countries which their private sectors have been unable or unwilling to meet and solve. The problems are greater in scope and character for a number of reasons. Products and processes are more sophisticated, and the necessary technology not only expensive (if the owners-often transnational corporations-are willing to sell), but also almost impossible to develop domestically with available talent. The problem of being competitive with production methods utilized elsewhere in the world is not simply a concern for export production, but also for the domestic market because of the penetration of these countries by capital from the more industrialized countries. Labor in these late, late industrializers is often better organized to make good its demands for a sizable share of the profits than was the case with the first industrializers. These problems (and of course there were others) were exacerbated in Mexico by the devastation of the Revolution, which extended through much of the second decade of this century. Mexico emerged from the Revolution without an entrepreneurial class capable of leading industrialization; consequently, a need arose for special institutional arrangements to confront and solve the problems of late, late industrialization. As Gerschenkron found in Europe, we find in Mexico (and to a certain extent in other Latin American countries) that state institutions have come to meet these problems. Our basic 
contention regarding the role of the state in the political economy of Mexico (although only limited evidence can be provided in this article) can be stated as follows: (1) The Mexican state has taken on the task of making capitalism work for Mexico; by (2) placing primary reliance on the private sector, promoting and strengthening it to lead the way in rapid economic growth; but (3) the state has stood ready to intervene in the economy as an institution of last resort, though sometimes an impatient one, acting as banker and as entrepreneur to deal with those problems that the private sector has been unwilling or unable to handle, or has tried to handle but failed. ${ }^{6}$

Gerschenkron's argument about the role of the state in industrialization in situations of relative backwardness can thus be extended to cover the case of Mexico-and will prove revealing. But, before proceeding, we should briefly take note of an incompleteness that his account has when considered as description, and an even more serious flaw that it has when considered as explanation.

His account is limited as a description because its central terms must be filled in historically. The conceptions of "problem," "last resort," and "inability", (or "unwillingness") have objective and subjective moments. The trajectory of growth-the mode of production in its fullest sense-throws up specific difficulties at particular points in time. But the manner in which these difficulties are defined as problems, the way in which the state's responsibility for solving them comes to be conceived, the recognition of the unwillingness or inability of private-sector actors, the judgment that no other solution can be found except by resort (last resort) to the instrumentality of the state-all these must be understood in light of the conceptualizing orientations of state institutions and leaders. And these orientations, in turn, change as problems are defined and confronted, as learning takes place, as generations and administrations change.

How Gerschenkron's account is flawed as an explanation may be noted simply by recognizing its functionalist or teleological character. Adducing that the inability of private-sector actors to solve the problems of late, late industrialization creates "needs" for action by the state does not explain why (still less how) the state acts to fulfill these needs. Such a functionalist explanation fails to account for the will (or lack of will) of the state to undertake to meet these needs and also fails to account for the state's power successfully (or unsuccessfully) to cope with these needs.

This article seeks to extend and develop Gerschenkron's suggestive approach. Looking historically at the Mexican case, we will endeavor to explain how the conceptions of "problem" and "last resort" have come to take on the meaning they have, and how the state created the power necessary to intervene directly in the economy. We will focus particular attention on the problem of the will or "orientations" of the state. Departing from interest-group theories or Marxist/instrumentalist theories that see state action as a result of groups or 
classes acting on the state from the outside, we will argue that the state does have certain "interests" or orientations of its own. But instead of simply assuming, a priori, the existence of these orientations, as Marxist/structuralist (or bureaucratic politics) approaches tend to, we will explore how the state comes to take on the orientations it does. We will argue that the Mexican state's orientations are historically filled in or taken on in three principal ways:

1. Following the Revolution, the Mexican state was reconstituted by a group of Sonoran constitutionalists (commercial farmers and petty capitalists). Though more nationalist than the preceding Porfirian regime, they once again set the country firmly on a capitalist road to development. Taking the United States as a model, they placed principal reliance on the still-frail private sector, but positioned the state to take forceful action in last resort in instances of private-sector incapability or unwillingness. This orientation was institutionalized in the Finance Ministry, the Bank of Mexico, and other public-sector banks in significant measure through an increasingly formalized training program.

2. Within this framing orientation, and within the ideological and political strictures of the Revolutionary heritage, difficulties posed by domestic and international conditions were diagnosed as problems, solutions were defined, and state interventions were carried through. Thus, (among many other interventions) the Mexican state built steel mills, paper and cement plants, and a railway construction firm; and it bailed out and took over bankrupt private ventures in automobiles, banking, sugar, etc. Once the state extended itself in this fashion, constituting or acquiring new agencies or enterprises, new orientations were filled in or taken on by the state; and because of their institutionalization, these new orientations became relatively stable, setting the state on a certain trajectory, susceptible more to marginal alterations than to wholesale change, even at the sexennial break.

3. Finally, changes of personnel (especially at the end of each presidential sexenio), while less imporant than these other modes, have altered the orientations of the Mexican state, in some instances (Cárdenas, López Mateos, Echeverría) more than others.

We will enlarge and substantiate this general argument principally through a discussion of a few of the more paradigmatic instances of state intervention. ${ }^{7}$ In a conclusion, we will seek to clarify the conception of the state that is being developed here, and we will address some issues concerning the changing relations of public and private sectors in Mexico.

\section{Reconstituting the State, 1917-40}

The political stability that was the masterful achievement of Porfirio Díaz made possible Mexico's first period of substantial and sustained economic growth during the years of his tutelage. Railroads were constructed, mining was 
modernized and expanded, commercial agriculture was developed, and exports were diversified.

A number of characteristics of that growth-particularly the foreign domination of certain leading sectors and the unequal distribution of the benefits of economic growth-served as the tinder that ignited into the Revolution. Diverse factions of landless peasants, workers, small landholders, and disgruntled politicians joined to topple Díaz in 1911 and then separated to contest the settlement.

In the aftermath of the fighting, those who finally prevailed and undertook the task of reconstituting the Mexican state were neither the agrarian radicals, who saw the Revolution as a social movement to bring massive land reform, nor those drawn from the more advanced factions of the labor and intellectual groups which nurtured socialist and anarcho-syndicalist ideas. Instead, they were predominantly of the middle class, many from the north-from Sonora particularly - some, like Carranza and Obregón, from landowning families (though not the largest of these), a few, like Calles, small businessmen. ${ }^{8}$ Two questions need concern us, the question of power and the question of intention or orientation. It is the latter of these-why the state chose to intervene in the economy for the purposes and in the manner that it did-that principally concerns us here, but we need to consider briefly the question of power because the successful intervention of the state into the economy presupposed a strong and unified governmental apparatus.

The power of the Mexican state to intervene directly into the economy grew out of the strong political institutions that were created on top of the fragmented class structure of postrevolutionary Mexico. In the dozen or so years following the Constitutional Convention of 1917, Presidents Carranza, Obregón, and Calles used their military power to crush armed opposition, built a strong bureaucracy relying heavily on técnicos (economists and engineers) in the key ministries of Treasury and Public Works, and were able to co-opt and control many dissident elements, an effort which culminated in the skillful construction of the National Revolutionary party (PNR) (predecessor to the Institutional Revolutionary party [PRI]). This increasingly strong central party institutionalized and monopolized access to political power, first by absorbing (or destroying) local caudillos and then by containing lower-class pressures through its labor and peasant sectors. ${ }^{9}$

These steps were made possible by the nonexistence of any social classes sufficiently powerful and well-organized to oppose them. The hacendados had been severely weakened by the Revolution. Peasant groups were debilitated by their regional organization, limited local goals, and the cooptation or assassination of their leaders. Labor, weak because of repression under the Díaz regime, remained crippled by control of the CROM, a corrupt labor confedera- 
tion highly dependent on governmental recognition for its right to strike. Finally, no national industrial or financial bourgeoisie had emerged during the foreign-dominated industrial growth of the Porfiriato (the Monterrey industrialists being a major exception), and those business interests that survived the Revolution found themselves either aided by government actions or too small and regionally isolated to oppose effectively the economic activities of the state.

The northern origins of the "'Sonora gang' that dominated Mexican politics until Cárdenas assumed the presidency in 1934 are important for understanding the framing orientations with which they infused the Mexican state. Because of the proximity to the United States, nowhere was the domination of foreign capital stronger than in the north. "By 1902 U.S. firms held more than a million hectares in Sonora; in Sinaloa they owned $50 \%$ of the productive deltaic plain and $75 \%$ of all irrigable land, where sugar, cotton, and fresh vegetables were raised for the market," 10 often the U.S. market. And foreign (mostly American) domination of mining and manufacturing, often abetted by the protection of Díaz and the cientificos, closed Mexicans out of other potentially productive endeavors. That foreign domination wove a strongly nationalist thread through their thinking, ${ }^{11}$ an orientation that took on concrete form in Article 27 of the constitution, and later in measures prohibiting foreigners from owning land, forbidding their participation in banking and insurance companies, nationalizing the petroleum, light and power industries, and limiting or excluding their equity participation in a growing number of manufacturing sectors. ${ }^{12}$

If the proximity to the United States had allowed a foreign domination which rankled, it also put before the eyes of these Sonorans the image of a modern, rapidly developing country. Beyond political consolidation, their primary concern was with economic growth, and the model to be copied was the capitalist system to the north with its dramatic successes in industrialization and in large-scale commercial argiculture. It is important to remember that no noncapitalist model existed to be copied-Russia's path was still uncertainbut it is more important that the Sonoran constitutionalists had no inclinations to socialism (and that no other social class forces pushed strongly in that direction). Still, the decision to reintegrate Mexico into the world capitalist economy left open a choice of routes. If the United States was to be the model for development, that was much more so in the sense of showing the shape and extent of what could be achieved than in the sense of showing a precise route to be followed. Among the alternatives available were a minimalist, laissez-faire state that would leave the speed and direction of growth to the private sector, and the Porfirian model of growth through active encouragement of foreign capital. The latter had just been rejected, however, and the former presumed the existence of the sort of national bourgeoisie that had led development in the United States and which was still nascent in Mexico: a "yeoman" agricultural 
class to promote agricultural modemization and an entrepreneurial class to lead industrialization. Mexico's peculiar conditions and its later start would require, it was recognized, a forceful role for the state. The orientation chosen would place primary reliance on the private sector, this private sector would be given inducements and assistance, particularly to follow certain directions marked out by the state as critical for development, but the state would stand ready to take on those tasks that the private sector was unable or unwilling to do.

In the early $1920 \mathrm{~s}$, these orientations came to be firmly embedded in the Ministry of Finance (Hacienda), and this ministry rapidly became the most powerful in the state apparatus (a position that has only recently been challenged). Indeed, the Mexican state during this early postrevolutionary period was, effectively, the president, the Finance Ministry, and the financial institutions around it (the Bank of Mexico, Nacional Financiera, etc.). The power of these financial institutions inside the state apparatus stemmed in part from Mexico's decision to abide by the rules of the world capitalist political economy: they were the institutions charged with stabilizing the currency, renegotiating debts, guaranteeing foreign loans, taxation, and control over budgetary allocation of these funds. Although such actions required presidential consultation and approval, these financial institutions have been nearly (again, until recently) the sole source of well-trained economists in Mexico. In-house training programs molded the orientations of those who passed through them to accord with the Treasury's view of matters.

The orientation of the Finance Ministry has changed over time, of course, partly in response to regime changes in Mexico, partly in response to shifting currents of economic thought outside Mexico. The concerns of Albert Pani and the economists around him who shaped the character of the Finance Ministry in the 1920s have been characterized as "orthodox" and neoclassical in orientation:

They sought to re-establish the nation's foreign trade position, restore confidence in the monetary system, and get channels of domestic trade and commerce operating once more. ${ }^{13}$

When Cárdenas came to power, those who staffed the key positions in the Finance Ministry and in the Bank of Mexico came to be more oriented towards Keynesian principles: growth in gross national product (GNP), aggregate investment, and employment became major economic indicators.

Beneath these changes in orientation ran a deep continuity, however. The Revolution had brought to the surface a series of radical demands or goals: for land redistribution, for recovery of national patrimony from foreigners, for substantial improvement in the terms of life for urban and rural lower classes. These radical goals did not coalesce into a coherent ideology, still less into a 


\section{Comparative Politics January 1980}

strategy for development. While these goals continued to be articulated by the revolutionary family, the strategy of economic development that came to be adopted, its guiding intelligence in the Finance Ministry, was one that saw these goals being pursued only insofar as they could be by-products of a certain kind of economic growth in which primary reliance would be placed on the private sector.

The common outlook among the middle- and high-level técnicos in the institutional complex demarcated by the Finance Ministry, the Bank of Mexico, and Nacional Financiera can be traced, to a large extent, to an in-house training program developed in the Bank of Mexico by Gonzalo Robles and Daniel Cosío Villegas and administered for a number of years by Robles. As a young man he had been a member of Carranza's retinue; he had studied engineering in the United States; and he had been centrally involved in the reorganization of the banking system. For a time, under Cárdenas, he was director general of the Bank of Mexico, moving later to become director of a new office in the bank, the department of industrial studies, from which he coordinated the training program. Promising young people were brought into the bank for a few years, sent off to foreign countries (often the United States) for graduate study, then returned for final shaping under Robles's careful attention. The orientation they received was the one we have already discussed: economic independence from the colossus to the north, industrialization, the importance of a middle class, primary reliance on the private sector, and the need for vigorous action by the state to create the conditions for private-sector investment and to do what the private sector would not or could not. ${ }^{14}$

Placing such primary reliance on the private sector ran into immediate difficulties. The national bourgeoisie was small and weak, and often disinclined to make long-term capital investments, preferring instead real estate speculation, commercial credit, jewelry, and the like. The only alternative, particularly if foreign investment was not to be encouraged, was state activity to foster the growth of a national bourgeoisie and to promote the kinds of conditions under which it would be inclined to invest. Major infrastructure investments in road building and in irrigation began in the mid-1920s. But nowhere was the early orientation of the state to be seen so clearly as in its actions to create a strong financial sector, and the consequences of its action here defined the terms of much of what would happen later.

Mexico faced nearly total financial collapse following the Revolution. Paper currency was worthless, most of the private banks were in ruins, and the country's standing in international financial circles had fallen so low that further credits were unobtainable. Calles and his finance minister saw the reorganization and resuscitation of a private banking system as a critical first step to generating domestic savings and investments and to attracting foreign 
loans. Under the new regime, foreign banks (and foreign ownership of domestic banks) were forbidden, and the private-sector banks were to be kept under close governmental supervision. The instrument of this supervision was the Bank of Mexico, created in 1925 to perform central bank functions. A complex scheme of reserve requirements became the mechanism by which private investment was to be channeled into high-priority sectors and by which savings could be extracted for public-sector investments.

A strong private banking system capable and willing to make needed investments could not be resurrected overnight. Calles, Cárdenas, and their key economic advisors acted to create a series of state development banks to do what the private sector could not or would not: the Agrarian Credit Bank, the Ejidal Bank, the Worker's and Industrial Development Bank, the Foreign Commerce Bank, the Small Merchant's Bank, and, most importantly, Nacional Financiera (NAFIN). The postrevolutionary leaders had come to define a strong, development-oriented banking system as a critical need, and state intervention as legitimate when the private sector was unable or unwilling to act. The particular kinds of public-sector banks needed were defined by more specific historical factors: the sectors earmarked to lead growth, and the needs and demands of the groups and classes that constituted the social foundations of the postrevolutionary Mexican state. ${ }^{15}$

Slowly, responding to the ministrations of the state, the private banking system began to grow, as well, in terms of assets and in terms of institutional strength and sophistication. One key measure in the state's nurturance, important in reorienting lending towards longer-term funding for industry and away from more speculative investments, was the authorization in 1932 and subsequent encouragement of financieras, a kind of investment bank. ${ }^{16}$ In the lack of an effective bond or stock market, the national bourgeoisie that has developed in Mexico has largely crystallized around the private banking system. It has come to be characterized by a series of groups-a dozen or so major ones and many smaller ones - each having a bank or bank complex at its center, the savings from which are utilized for investments in affiliated manufacturing, mining, and/or commercial enterprises. ${ }^{17}$

The importance of what was done in the financial sector in the 1920 s and 1930s does not lie in the fact of the state's intervention; strong state participation in the banking sector is hardly unusual, particularly in developing countries. What is to be stressed is that the pattern set down in the banking sector was one that would be repeated elsewhere, in manufacturing, and in mining: primary reliance was placed on the private sector, but the state stood prepared to do what the private sector was unable or unwilling to do. And when the state would act in last resort in these other sectors, it would act primarily through the instrumentality of the public-sector development banks. 
Mexico's economists conceived of a total network of economic institutions and processes necessary to complete the structure they were creating, and if the private sector could not supply these, it seemed the obligation of the state to do so, in the interests of the private sector itself. ${ }^{18}$

Under the Cárdenas regime (1934-40), there were important state economic interventions in nonbanking areas: the state became the major or sole owner in the light and power industry, the railroads, and the petroleum industry. In each of these cases, however, it was foreign private investment that was being challenged by the state; the intervention was spurred either by serious bottlenecks, that were being created by foreign reticence to make needed investments (light and power, railroads), or challenges to the sovereignty of the Mexican state (oil companies); and in each of the cases it would have been difficult for private Mexican investors to solve the problems because of high risks, large initial investments, and long-term horizons on profits. ${ }^{19}$ The much stronger action that Cárdenas was able to take toward foreign investment than Calles, and Cárdenas's distinctive exercise of political power on behalf of the workers and peasants, should not be allowed to obscure the strong continuity with regard to the state's role in the economy. Nothing is so important in explaining this continuity as the continuity of personnel in key financial positions: Luis Montes de Oca, for example, president of the Bank of Mexico under Cárdenas, had served as general comptroller and finance minister in the cabinets of Calles's Maximato; and Cárdenas's finance minister, Eduardo Suárez, retained the same position in the subsequent administration of Avila Camacho, as did Antonio Espinosa de los Monteros, director general of Nacional Financiera. ${ }^{20}$

\section{Expansion of State Intervention, 1940-70}

The decades of the 1920s and 1930s had been ones of political and economic reconstruction in Mexico. The foundations were laid in those years for the surge of industrialization that began in the 1940s, and that was to be sustained into the 1970s. The Great Depression, in decreasing the volume of world trade, had provided some stimulation for domestic production of consumer goods in Mexico, and World War II added to the insulation of the domestic market from imports the possibility of exports to the United States. Guided by its orientation toward primary reliance on the private sector, the Mexican state (or, more properly, the "effective" state centered around the president, the Treasury, and public financial institutions) acted to encourage the private sector to respond to the possibilities created by these changes in the international political economy. In 1947, the war-induced protection of local industries over, the government implemented a scheme of tariffs and quotas to sustain the import substitution industrialization into which circumstances had already maneuvered Mexico. 
The assistance of the government to the private sector took an array of forms: financing for new businesses through its development banks, basic infrastructure facilities and services, and beneficial tax policies. Public-sector purchases of goods and services provided important markets for some young firms. The manner in which Cárdenas had reorganized the political institutions (especially the PRI) permitted a considerable measure of control over the labor force through cooptation of its leaders, though there was occasional resort to coercion as well. And, in 1954, after two significant devaluations in less than a decade, the state took steps to damp down inflation: the policy of stabilized development (desarrollo estabilizador) had emerged-a defining characteristic of Mexico's growth strategy into the 1970s.

The emerging national bourgeoisie responded quickly to international conditions and government stimuli (though transnational corporations did so too, especially during the $1950 \mathrm{~s}$ and $60 \mathrm{~s}^{21}$ ). But the context of late, late industrialization threw up new problems that the private sector was unable to meet. In a range of basic industries, the investments that were necessary to sustain the pace of industrialization, and, eventually, to "deepen"' it beyond the light consumer industries of the "easy" stage of import substitution, were of such magnitude, high risk, or long-term character that they would not have been made had not the state stepped in. The public-sector banks were the principal instrument for the state's intervention, and the most important of these was Nacional Financiera (NAFIN). ${ }^{22}$

Founded in 1934 to perform a complex variety of functions, including the development of a stock exchange and a capital market for public bonds, NAFIN was reorganized in December 1940 to make the promotion of industrial development its principal focus. NAFIN rapidly became the major institutional arm of the state's entrepreneurial activities, the instrumentality by which the state's potential power, in relation to a still-maturing national bourgeoisie, became actualized.

NAFIN's influence in shaping the character of state entrepreneurial activities is in large part due to the powerful, relatively autonomous position it has within the government. It has maintained its own financial base through a steady record of earnings (which it has tended to capitalize), through the sale of certificates of participation in the bank's equity investments, and through continuing access to foreign loans (the Ex-Im Bank, for example). The relative autonomy of NAFIN from the tricky currents of Mexican politics is enhanced as well by the close coordination of its activities with the powerful Finance Ministry and the Bank of Mexico. Representatives from both institutions sit on NAFIN's board of directors, and there is a strong tendency for technical personnel to move among the three institutions, imbuing them with a common outlook. Moreover, there tends to be more continuity of top officials within these institutions than in other ministries and state agencies. 
The bulk of NAFIN's loans and investments have gone to public-sector infrastructure projects in railroads, irrigation, electric power, telecommunications, and the like. If we pass over these to concentrate on NAFIN's industrial promotions, it is only because such infrastructure investments are a more common and less contentious sort of intervention by the state into the economy of a developing country. NAFIN's financing of industry has been considerable, steadily accounting since 1950 for between one-third and one-half of the banking system's total financing of industry. ${ }^{23}$ By 1945 , NAFIN held stock in thirty-five corporations and was majority owner of five, and by 1961 :

it was a creditor, investor or guarantor for 533 business enterprises of all kinds; it held stocks in 60 industrial firms; and it was majority stockholder in 13 firms producing steel, textiles, motion pictures, plywood, paper, fertilizers, electrical energy, sugar, lumber and refrigerated meats. ${ }^{24}$

From the beginning, NAFIN's activities were legally circumscribed to keep it from emerging as a direct threat to the private sector. In practice, particularly in its equity investments, NAFIN has tended to confine its entrepreneurial activities to cases in which the private sector was unable or unwilling to make investments in areas seen as crucial for industrialization. ${ }^{25}$

Wartime shortages and the failure of the private sector to meet the resultant needs led to NAFIN's initial investments in paper, cement, and steel. ${ }^{26}$ Its involvement in the steel industry is particularly dramatic and indicative of the more general pattern. ${ }^{27}$ By the late 1930s, Mexico was importing two-thirds of the steel needed for domestic consumption. The onset of the war meant that imported steel would no longer be available. A group of private bankers and investors drew up a plan for a new steel mill, but soon found that the project was well beyond their financial and technical resources. NAFIN intervened, borrowing $\$ 6$ million from the Export-Import Bank. At first it tried to avoid majority ownership of Altos Hornos, as the new firm came to be called, buying the whole of the venture's first bond issue and a majority of the preferred stock, but only a quarter of the common stock. The firm took longer to move into production than anticipated, and further financing was needed, which the private interests would not commit. By 1947 NAFIN was majority owner of the firm.

Altos Hornos was only the beginning of NAFIN's-and the government's-involvement in the steel industry. In 1961 NAFIN extended credit to allow Altos Hornos to acquire the La Consolidada steel works, lest that firm should fail. As the large private firm Fundidora de Fierro y Acero de Monterrey (founded in 1893) felt the need to modernize its equipment, and as private investors have been hesitant to supply the necessary financing to the aging firm, NAFIN has increasingly filled the gap, by 1975 coming to hold 
one-third of its equity. Similar circumstances have led NAFIN to take on a minority equity holding in Tubos de Acero, another privately initiated firm. And with the Mexican demand for steel far outstripping the capacityof these existing firms, NAFIN has become involved in the development of a new steel mill, the Siderúrgica Lázaro Cárdenas-Las Truchas (SICARTSA), a venture of such size and sophistication as to be well beyond the capability of the private sector.

In some cases, the hesitation of the private sector to make important investments stemmed from considerations of political risk rather than simply from financing or technical drawbacks. After the Alemán administration came into office in 1946, feasibility studies done by U.S. consultants and the Bank of Mexico (Gonzalo Robles's department of industrial investigations) showed the construction of railway freight cars, then imported used from the United States, to be a prime industry candidate for import substitution. Where other such proposed projects found willing private investors, this one did not. The market volume was certain enough, but there would be only one buyer, a state-owned enterprise. Further, the railways had been operating at a loss and were slow to pay bills. Forcing collection from a state enterprise would undoubtedly be difficult. With funding provided through NAFIN, the state itself undertook the creation of Constructora Nacional de Carros de Ferrocarril in 1952. ${ }^{28}$

Although NAFIN's success and profitability have made it a target for charges that it has intruded into areas that should have been left to the private sector, its entrepreneurial activities have greatly benefited the private sector, and its own equity investments have been centered in those fields and in those projects in which circumstances "placed the minimum effort required well beyond the capacity of the private entrepreneurs and investors of a still newly developing economy"':

The larger capital outlays required, the more complex operations which rendered new ventures technically more difficult to launch, and the higher risks deriving from uncertainties of costs and production flows as well as from the greater market imponderables (i.e., greater than those encountered in industrialization to substitute for consumer goods imports). ${ }^{29}$

The last-resort character of the interventions of the state into the Mexican economy can be seen in the efforts of NAFIN (and other state institutions) to promote and finance projects of critical importance to national industrialization which were beyond the capabilities of the private sector, but this last-resort character can be seen as well in the Mexican state's willingness to bail out private-sector firms which were on the brink of failure. Although such failures often involve incompetence, they must be seen against the background of the difficulties faced by national entrepreneurs in meeting the demands of import 
substitution industrialization. The cases of Diesel Nacional (DINA) and the Sociedad Mexicana de Crédito Industrial (SOMEX), an industrial firm and a banking firm, are two of the major instances of a number that could be considered here.

The initiative for Diesel Nacional came originally from two private-sector promoters, Bruno Pagliai and Luis Montes de Oca. Together, and on the basis of studies done by themselves, Fiat and NAFIN, they proposed to manufacture diesel trucks in Mexico using Fiat technology. When these private investors were unable to raise the capital necessary for the venture, they sought publicsector assistance. NAFIN subscribed to 59.5 million pesos of stock; the private investors put in 10.5 million; and Fiat was allotted 6 million as payment for its cooperation and technology. ${ }^{30}$ Diesel Nacional (DINA), which started operations in 1954, fared poorly. The Fiat truck was ill-adapted to Mexican roads and cargos, the firm was induced to buy expensive and unnecessary machinery from Fiat, and complex problems of distribution were never adequately solved. Efforts to improve sales and profits by domestically assembling automobiles then popular in Mexico (Fiat 1100s and 1400s) proved insufficient. Even without these problems, it is difficult to see how the firm could have succeeded without protection from imported vehicles. By 1958 the firm was nearly bankrupt and the private investors eager to withdraw. The Mexican state, acting principally through NAFIN, bought out their shares and recapitalized the venture. The Mexican state had become sole proprietor of a major firm in the rapidly developing Mexican automobile industry. ${ }^{31}$ DINA itself has expanded, most often following "last resort" lines. When FANASA, the Mexican-owned manufacturer of the ill-fated Borgward automobile, went bankrupt, and none of the other auto firms showed interest, DINA stepped in to utilize the firm's plant and equipment. Making contracts with International Harvester (and more recently with General Motors), it organized a subsidiary called Maquiladora Automotriz Nacional to assemble pickup trucks; and, in joint venture with North American Rockwell, DINA and NAFIN set up DINA-Rockwell to manufacture heavy-duty truck and bus axles.

The case of SOMEX is similar. Founded in 1941 by Dr. Antonio Sacristán, a Spanish immigrant, SOMEX rapidly became one of the most important financieras in Mexico. It promoted and financed industrial enterprises in such disparate fields as automobile assembly and parts manufacture, household appliances, and the canning and fishing industries. By 1962 SOMEX owned or participated in more than forty enterprises, but was on the point of bankruptcy, beset by problems of internal administration and an overlong portfolio of unprofitable firms, Sacristán having been more venturesome than other private entrepreneurs. The Mexican government could not allow the failure of such a major private bank. A number of the enterprises it owned were in sectors that had been marked as priorities for industrial growth; the resultant unemployment 
would have caused considerable hardship and would have generated substantial pressures for curative government action; and the failure would have shattered public confidence in the banking system, savings from which were crucial for both public- and private-sector investments. The viability of the entire growth strategy would have been threatened. In taking over SOMEX, the state acquired not only a second major industrial development bank, but also holdings in (a majority position in many) over forty firms. ${ }^{32}$

The Mexican state's acquisition of unprofitable private sugar mills at an accelerating rate during the 1960 s and 1970s would seem to present another example of state sector intervention and expansion resulting from private-sector failure, but this case is more complicated. ${ }^{33}$

To maintain the low rate of inflation required by the post-1954 policy of desarrollo estabilizador, price controls were instituted on basic commodities. In 1958 they were placed on sugar. Labor costs in the sugar industry were not so strictly controlled, however, and during the next ten years, labor costs rose $\mathbf{7 5}$ percent. The expansion of land under cane cultivation and the adoption of more efficient agricultural methods were somewhat limited by the ejidal character of neighboring lands, which the government was committed (at least to some degree) to protect. Faced with rising costs but unable to expand production or to raise prices, the private mills began to go bankrupt. The state's first response was to create a special state banking institution, the Financiera Nacional Azucarera, to channel investment capital to the industry. When that proved insufficient and the mills continued to lose money, the state, now often the major creditor, stepped in and took them over. A series of efforts to restructure the industry during the 1970 s were to no avail. By 1969 , eighteen mills (accounting for 30.7 percent of national production) were under government control; by 1975 that number had increased to thirty-one (50.5 percent of national production).

The failures of the private-sector firms were the immediate cause of the state acquisitions in the sugar industry, but those failures were themselves induced by government policies generated by orientations institutionalized in other state agencies aimed at solving other problems of the industrialization strategy, particularly the problem of inflation. Sugar operations became so unattractive that existing owners would not make needed new investments and no buyers could be found for struggling firms. The state stepped in not merely to recover the loans it had made, but also to maintain a major source of rural employment and to boost sugar production, production needed so that domestic demand could be met without upward pressure on prices and so that there would once again be export sales.

We have thus far explored two reasons for direct state intervention: the reticence of the private sector to make needed investments, and the failures of already existing private-sector enterprises. But there are also cases in which 
private-sector investment was available and successful but in which the state intervened nevertheless; they are cases in which the private investment was foreign. Private foreign investment raises special considerations, but not ones that completely deviate from the last-resort character of the interventions of the Mexican state. Earlier we considered a number of state actions towards foreign investors during the Cárdenas regime, arguing that these interventions tended to be triggered by problems (bottlenecks, etc.) that were unlikely to be solved so long as the firms involved remained in foreign hands. After World War II, however, nationalization became a very uncommon response of the Mexican government to foreign investment: "Mexicanization" became the preferred strategy. In order to regulate and control the activities of transnational corporations and to protect and promote the growth of a Mexican national bourgeoisie, foreign investors were first encouraged and then required to share majority ownership (equity) with Mexican partners. ${ }^{34}$ It has often proved difficult to locate willing and able Mexican private investors for a variety of reasons: the high initial expense of the 51 percent equity, the weak capital market, and differences between the foreign investors and potential Mexican investors with regard to the reinvestment of earnings, etc. For a time, the government helped subsidize Mexicanization through tax incentives and other concessions; but, more recently, finding these measures to be too costly in terms of tax revenues foregone, it has promoted Mexicanization by itself acting as an investor of last resort, providing that portion of the Mexican investment which private Mexican capital has been reluctant to put forward. In the mining industry, for example, NAFIN has participated in the Mexicanization of Azufrera Panamericana, Compañía Minera Autlán, and Anaconda's giant Cananea mine. In the agricultural machinery industry, one in which there had been considerable pressure to Mexicanize, some of the firms had put 51 percent of their shares in trust while they searched for suitable Mexican partners. After several years, when no private Mexican investors showed interest in John Deere, NAFIN purchased the shares itself. In these cases, the "need" for state intervention arose not so much from the financial and technical requisites of the industrialization strategy as from the political requisites of the Mexicanization posture towards foreign investment.

Acting primarily as an institution of last resort, the Mexican state has founded banks, promoted and financed firms in new and critical areas, bailed out bankrupt ventures, and participated in the Mexicanization of foreign-owned corporations. The total extent of these interventions of the state into the Mexican economy is considerable - in 1976 the secretary of national property's Directory of State Enterprises listed 470 firms. ${ }^{35}$ In 1974 these state sector enterprises accounted for about 10 percent of Mexico's gross domestic product (GDP).

Two final points of some importance need to be made concerning the manner 
in which new orientations are taken on by the Mexican state. Through lastresort intervention, a large number of new enterprises have been added to the Mexican state, but, to an increasing extent, the orientations of these state firms have come to be informed by the very character of the economic activity in which they are engaged, and have displaced last-resort considerations. Shortly after it first began production, Altos Hornos, one of NAFIN's first major projects, began to move towards more fully integrated operations-much in the manner of other major steel companies, public and private, elsewhere in the world. It has moved aggressively to promote ventures guaranteeing it raw material supplies, to add firms that make efficient use of its by-products, and to acquire competitors to consolidate its product liens. Today, Altos Hornos stands at the center of a complex of thirty-eight firms. Another instance of the same pattern: when Chrysler's Mexican subsidiary was compelled under Mexican law to divert majority ownership in its diesel engine manufacturing concern, Motores Perkins, the buyer was state-owned Diesel Nacional (DINA), the other major producer of automotive diesel engines. Not waiting to see if any private investors might be interested in the acquisition, DINA moved swiftly to acquire its competitor. In these cases and in a number of others, state firms acquired for last-resort reasons have themselves intervened in the economy for quite different purposes, acting much in the manner of private firms in the same line of business.

Finally, political factors have also been important in reshaping the orientations of state enterprises. Though they are difficult to document, there surely are instances of acquisitions and expansions by state firms whose top officials are seeking to enhance their power and prestige in political circles. Just as surely, there are instances of the use of public office for personal profit, and these, too, alter the state's orientations. Perhaps still more important are personnel changes, particularly those that come at the sexennial change of administration. A variety of factors, including continuities among lower-level técnicos, limit how dramatic the resultant change in orientation may be, but some significant redirection has taken place. SOMEX, for example, went through a period of retrenchment, consolidation, and reorganization after the government bailed it out in 1962. This made possible SOMEX's post-1970 return to the more aggressive investment attitude it had evidenced while in private hands, but the change was in part fostered by the top SOMEX appointments made under the more statist and interventionist Echeverría regime. A more dramatic recent example is state expansion in the mining sector, initiated principally through the Comisión de Fomento Minero (CFM), an agency attached to the Ministry of National Patrimony. Created in 1958, this distinctively nationalist-oriented ministry was initially concerned with the Mexicanization of mining through private-sector investment in the foreign-owned companies which dominated the industry. The more statist orientation of the 
Echeverria administration enhanced the power of this ministry within the government, however, and encouraged its técnicos (many of them brought in by the Echeverría administration) to have the state make mining investments itself, generally through the CFM. In the five years from 1970 to 1975 , the state's share in mining investments doubled from 17.8 percent to 35 percent. $^{36}$

\section{Conclusion}

Alexander Gerschenkron's approach to the role of the state in the process of industrialization, while pointing in the proper direction, nevertheless (we argued in the introduction), has a certain incompleteness when taken as description, and a deeper flaw because of its functionalist character, when taken as explanation. Gerschenkron does pose the problem of the state in a serious way; he does see that the state has an inherent role marked out for it and that this role varies in relation to historical circumstance. And yet Gerschenkron has no theory of the state (nor even a firm conception of the state). His approach can grasp the role that the state must play if industrialization and growth are to proceed, but, in its functionalism, his approach gives no account of either the state's power or of its orientations to play the historical role that it has. These are correctable faults. The sketch we have just provided of the economic interventions of the Mexican state since the Revolution contains an implicit conception of the state which we now aim to make explicit.

\section{The question of state orientations}

The taken-on/filled-in character of state orientations. Gerschenkron has no answer to the question of political will: How do the orientations of the state arise? He identifies tasks that only the state can perform, and (as if by magic) produces a state that is oriented to and capable of fulfilling those tasks. Speaking rather broadly, we can identify two sorts of strategies for explaining why the state acts as it does. Exogenous explanations see the state as responding merely to pressures applied on it externally by groups, classes, or class factions. Group theory explanations are of this sort ${ }^{37}$ and (notwithstanding considerable differences) "instrumentalist" Marxist approaches tend to favor this exogenous strategy. ${ }^{38}$ Endogenous explanatory strategies, on the other hand, understand the state as having orientations of its own that guide its action from within. "Structuralist" Marxist explanations are predominantly of this sort, ${ }^{39}$ as are "bureaucratic politics" approaches ${ }^{40}$ (though these are theoretically much more rudimentary and short-term in character). There can be no question of choosing a priori between these two explanatory strategies, though one or the other may be more important in particular cases. Externally applied pressures 
have been important in limiting and shaping the actions of the Mexican state, particularly in recent years, but the burden of the argument in this paper is that one must look to the Mexican state's own orientations to explain its economic interventions since the Revolution. The insufficiency of the exogenous strategy can be seen in trying to explain why the Mexican state originally took on the orientation that it did with regard to economic growth. Beginning in the 1920s, the Mexican state took on the task of developing a national bourgeoisie, and in no way can the very frail national bourgeoisie of that time be seen as a pressure group sufficiently powerful to orient the state's actions.

Neither the "bureaucratic politics" approach nor the structuralist-Marxist approach can be relied upon for an understanding of how the state's own orientations arise, however. The former merely takes these as given. The latter views the state as acting in accord with an internal logic that arises from the need for an institution to resolve the contradictions of capitalist production, particularly those that arise between the various factions of the capitalist class; but, like Gerschenkron, the structuralist approach risks falling into the functionalist error (the orientation is called forth simply by the need), and it has tended to be excessively abstract and inattentive to the specific shape those contradictions take in a particular society. ${ }^{41}$

This paper argues that the state has orientations of its own and suggests three ways in which these orientations can be taken on or filled in. First, at those historical moments when the state is constituted (more often reconstituted), those elements that have seized the political initiative can set down the initial orientations of the state by devising an array of institutions which embody their ideological vision, by coalescing class alliances to form the social foundations of the reconstituted state, and by formulating legitimations to transform their might into right. In postrevolutionary Mexico it was the constitutionalists (small businessmen, commercial farmers) from Sonora who used military power to capture political control and reconstitute the state. The orientation with which they imbued key state institutions (the Finance Ministry and the banks associated with it) defined a growth strategy that placed primary reliance on the private sector, but which held the state in readiness to intervene in last resort in instances of private-sector incapability or unwillingness. These initial orientations were crucial: the character of the Mexican state became set in ways which delimited the direction of future state expansion and which gradually constrained the possibility of anything but marginal changes in state orientations, unless the state were captured and reconstituted by a wholly different element.

Secondly, over time, particular crises or problems arise which the state may see as necessary to confront and solve (it may be more or less reluctant to see any particular problem as its responsibility). The mere existence of a problem or crisis, however, does not automatically cause the creation of a state institution 
to deal with it. Whether or not the state will respond will itself be shaped by already existing orientations. Acting on the basis of orientations that have already been taken on and institutionalized within the state apparatus, new problems thrust upon the state will be defined in certain ways and institutional mechanisms created or adapted to deal with them. In Mexico, an initial set of last-resort orientations towards problems of savings and investment were institutionalized in a complex of state-sector financial institutions. In the face of private-sector difficulties in certain key sectors, the state intervened, creating enterprises in fields as diverse as steel and fertilizers, and taking over enterprises engaged in dozens of other endeavors.

NAFIN, to take one interesting example, was originally created out of the continuing concern of the state to develop an adequate financial system; it was particularly charged with the development of a stock and bond market. But as the international economy changed (due to the Great Depression and World War II) and import substitution industrialization became both a necessity and an opportunity, NAFIN was reorganized to serve as an industrial development bank. The orientation that came to guide the bank during the 1940s has more or less continued to inform its activities, though there have been some changes (a greater concern with regional development and with small businesses, for example). As the state has acquired or created various industrial enterprisesAtenquique, DINA, etc.-in response to problems of private-sector incapability or failure, new organisms have been added to the state, with their own distinctive tasks and orientations, and these institutionally based orientations have thus been added to the state's repertoire. Altos Hornos and SOMEX were acquired by the state acting out of last-resort considerations, but these state enterprises themselves, acting in response to their own problems, needs, and guiding orientations have acquired or initiated other ventures in ways that move beyond last-resort considerations strictly defined, often paralleling the orientations of private-sector firms in the same industry. Hence, Altos Hornos's expansion for vertical integration, or DINA's acquisition of Motores Perkins. In other instances, political ambitions on the part of directors of state enterprises have generated expansions or acquisitions by these firms in situations that cannot be seen to be limited to last-resort considerations.

Changes in government personnel are a third way in which different orientations can be filled in or taken on by the state. The most important mechanism for such changes in postrevolutionary Mexico has been the sexennial change in administration, and the substantial turnover in key officials each new president institutes. Despite the enduring role of the Partido Revolucionario Institucional, new presidents have altered the orientations of the state, often by adding new tasks to its repertoire: the Lopez Mateos administration brought with it a concern for strong state action to restimulate import substitution; Echeverría brought a decidedly more statist orientation than his predecessors. Changes in 
presidential administration, however, are not likely to provide channels for a group representing a different social-class faction to "capture" the state and alter, to any dramatic extent, the state's orientations. Although there is considerable debate over whether Cárdenas's mobilization of peasants and labor in the 1930s, and his replacement by Avila Camacho's more conservative administration in 1940, constitute such changes, the sedimentation of state institutions in the post- 1940 period has made changes in orientations increasingly difficult, except on the margins. And, in the ministries and agencies concerned with economic growth in Mexico, there has been an unusual continuity of outlook, the product of continuity of personnel, constraints set by institutionalized orientations the state had already taken on, and of enduring features of the domestic and international environment.

The definition of problems. Understanding the orientations of the state helps us to move beyond the incompleteness of Gerschenkron's account in its descriptive character; it allows us to understand how such central terms as "problem" are defined historically. Although many of Mexico's problems had a certain "objective" character which would make them recognizable in other developing countries (the problem of rapid capital accumulation, balance-ofpayment deficits, etc.), we also saw how such problems were historically defined by the particular political dynamics and ideological currents in Mexico. The political decision to accept a stabilization program and orthodox monetary policy in the early 1950 s, for example, led to another political decision to control sugar prices. Coupled with a political decision to let wages rise in the industry, a situation was created where the private sector became unwilling to invest in sugar production. This created political problems (unemployment in sugar regions, popular-sector unrest if the prices of basic commodities were not kept low) and an economic problem (loss of export revenue). The state responded by taking over the sugar mills. Another example: it was the political definition of foreign investment as a problem and of Mexicanization as a solution that induced "last-resort" state purchases of equity in TNC subsidiaries.

The question of state power State intervention into the economy of late dependent industrialization does not depend simply on prerequisites needing to be filled or problems that would be left unsolved if left to private-sector institutional arrangements. The state must have the power to intervene and a full explanation must take power as a variable, not a given. We have argued that the Mexican state had the power to act as a banker and entrepreneur because of the way in which strong political institutions were created after the Revolution and because of the weak and disorganized nature of the private sector at this time. Further, certain factors stemming from Mexico's place in the international political economy created possibilities for state action. The Great Depression 
and World War II opened the possibility for pursuing import substitution industrialization, and the threat of conflict in Europe somewhat tempered U.S. reaction to the 1938 oil nationalizations. Other factors, however, severely limited the power of the state: the needs of the Obregón and Calles governments for U.S. diplomatic recognition in order to refinance the huge external debt not only would have made difficult a development strategy that challenged private capital, but actually did force these regimes to stop their moves against U.S. oil companies.

These few remarks are only meant to be suggestive. This paper has been principally concerned with the problem of orientations, and we are far from presenting a full explanation of the growth, maintenance, and limits of the power of the Mexican state. We might close, however, by touching on very current matters which any such explanation would have to take into consideration-two factors placing increasingly stiff limits on the power of the Mexican state to intervene in the economy.

One is increasing resistance from the very national bourgeoisie the state helped to create. Sometimes this resistance has taken dramatic, public form, such as the determined opposition that President Echeverría faced from the Monterrey business groups, particularly the flight of capital that occurred in the last years of his regime. But there are other, less visible, but surely important ways that the activities of the national bourgeoisie-which now constitutes a crucial part of the social foundations of the state-limit state action. Foremost, perhaps, is the systematic connection between state spending and private-sector investment. The state finances many of its activities through a complex scheme of reserve requirements in the banking system. Increased state expenditures lead to high interest rates and a tightening of credit for private investment, but this only increases the need for state expenditures as the state is increasingly compelled to act in last resort in the face of declining private-sector investment. The state-business-labor pact (Alianza para la Producción) organized by President López Portillo when he took office in December 1976 was aimed at solving this dilemma, one of its key terms being an agreement by the state to cut spending in return for increased private-sector investments. The problem persists, however. Government officials are showing impatience with what they consider private-sector heel dragging and urging more public-sector investment.

Mexico's substantial foreign debt constitutes a second obstacle to state intervention in the economy.${ }^{42}$ Partly to avoid dependence on the private sector while making investments needed to overcome the potential exhaustion of the "easy stage" of import substitution industrialization, the Mexican state has engaged substantial foreign debts to finance its activities. The increased willingness of transnational banks to lend to certain lesser-developed countries like Mexico in the late 1960 s and early 1970 s helped make possible the expansion of 
state economic activities engineered by the Echeverría regime. Inflation and a fast-growing debt service constituted new problems, however. Under pressure from the International Monetary Fund (IMF), the World Bank, and private transnational banks, Mexico was forced to devalue twice in the last months of 1976 and had to make promises to restrain governmental expenditures. The internal pressures of the national bourgeoisie compounded by the external pressures set by foreign indebtedness have created a contradiction: the ability of the state to continue to act as an institution of last resort, while at the same time following a policy of primary reliance on the private sector, seems to be severely threatened at this point in Mexican history.

\section{NOTES}

*The theoretical arguments in this paper benefited greatly from ongoing collaborative work with Dr. Morris J. Blachman. The skillful research assistance of Bonnie Sharpe was important in collecting the case data used for this paper. Funding from the following foundations made possible the larger research project of which this paper is a part: the Tinker Foundation, the Social Science Research Council, the Carnegie Endowment for International Peace, the Doherty Foundation, and the National Endowment for the Humanities.

1. See, for example, Roger D. Hansen, The Politics of Mexican Development (Baltimore, 1971), esp. chap. 4, "Fruition: For Whom?"'; Pablo González Casanova, Democracy in Mexico (New York, 1970); Susan Eckstein, Poverty of Revolution (Princeton, 1977); Judith Adler Hellman, Mexico in Crisis (New York, 1978).

2. A 1971 ECLA study, for example, showed that the Mexican state owned twenty-six enterprises in the manufacturing sector compared with four for Argentina, three for Brazil, three for Columbia, four for Chile, five for Peru, and six for Venezuela. "Public Enterprises: Their Present Significance and Their Potential in Development," Economic Bulletin for Latin America, 16, no. 1(1971), pp. 1-70, Table 4.

3. The full thesis will be treated in a larger work now in progress.

4. Alexander Gerschenkron, Economic Backwardness in Historical Perspective (Cambridge, [Mass.], 1966), p. 7.

5. For a discussion of the differences between "late" industrialization in Europe and "late, late" industrialization in Latin America, see Albert Hirschman, "The Political Economy of Import-Substituting Industrialization in Latin America,' Quarterly Journal of Economics, 82, no. 1 (1968), 1-32.

6. For an alternative view which places emphasis on the role of the values of private-sector industrialists in economic growth, see Seymour Martin Lipset, "Values, Education, and Entrepreneurship,' in Lipset and Aldo Solari, Elites in Latin America (New York, 1967).

7. Information regarding these cases has been drawn from confidential interviews conducted by the authors in 1976-77, from documentary sources published by the Mexican government, and from secondary sources.

8. See Arnoldo Córdova, La Ideología de la Revolución Mexicana: La Formación del Nuevo Régimen (Mexico, 1973) for a detailed analysis of the character of the postrevolutionary Mexican state.

9. For a fuller discussion of the process of political centralization, see Hansen, Politics of Mexican Development; and Robert E. Scott, Mexican Government in Transition (Urbana [Ill.], 1964).

10. Eric Wolf, Peasant Wars of the Twentieth Century (New York, 1969), pp. 38-39.

11. For more detailed discussions of Mexican nationalism, see William P. Glade, Jr., "Revolution and Economic Development,"' in Glade, and Charles W. Anderson, The Political Economy of 


\section{Comparative Politics January 1980}

Mexico (Madison, [Wisc.], 1968), pp. 28 ff.; and Frederick W. Turner, The Dynamics of Mexican Nationalism (Chapel Hill [N.C.], 1968).

12. On these measures, see Harry K. Wright, Foreign Enterprise in Mexico (Chapel Hill [N.C.], 1971); and Douglas Bennett, Morris Blachman, and Kenneth Sharpe, "Mexico and Multinational Corporations: An Explanation of State Action," in Joseph Grunwald, ed. Latin America and World Economy: A Changing International Order (Beverly Hills, 1978), p. $257-82$.

13. Anderson, "Bankers as Revolutionaries" in Glade and Anderson, pp. 113-14. He continues, "Nurtured on the economics of the Díaz period, these latter day cientificos largely accepted the legitimacy of the intricate and many-faceted institutions of the modern economic system as it had been elaborated and developed in the advanced nations of Europe and North America .... [T] hey anticipated no radical departure in their planning from the economic institutions and practices prevailing in the industrialized nations. Accepting this model for the economic modernization of Mexico, they conceived their mission, in a sense, as that of implementing programs that were the unfinished business of the Porfiriato." pp. 114-15.

14. Personal interviews with Gonzalo Robles and other government officials who participated in the training program.

15. For an excellent discussion of the formation of state development banks, see Anderson, "Bankers as Revolutionaries."

16. On financieras, and more generally on the development of the banking system, see Dwight Brothers and Leopoldo Solís, Mexican Financial Development (1940-1960), (Austin [Tex.], 1966).

17. For a current portrait of these groups, see Salvadore Cordero and Rafael Santín, "Los Grupos Industriales: Una Nueva Organización Económica en Mexico," Cuadernos del CES, 23 (Mexico: El Colegio de Mexico, 1977). Discussion of the origins of the national bourgeoisie may be found in Sanford Mosk, Industrial Revolution in Mexico (Berkeley, 1950), esp. chap. 2; and in Flavia DeRossi, The Mexican Entrepreneur (Paris: Development Centre of the Organization for Economic Cooperation and Development, 1971), pp. 157, and 143-44.

18. Anderson, "Bankers as Revolutionaries," p. 118.

19. On the petroleum case, see Lorenzo Meyer, México y los Estado Unidos en el Conflicto Petrolero (1917-42), (Mexico, 1968). On light and power, see Miguel S. Wionczek, El Nacionalismo Mexicano y la Inversión Extranjera, (Mexico, 1967). For an elaboration of the argument presented here, see Bennett, Blachman, and Sharpe, "Mexico and Multinational Corporations: An Explanation of State Action," loc. cit.

20. Nora Hamilton, “Mexico: The Limits of State Autonomy,' Latin American Perspectives, 2 (Summer 1975), 86-7, 96.

21. R.S. Newfarmer and W. Mueller, Multinational Corporations in Brazil and Mexico: Structural Services of Economic and Non-Economic Power (Washington, D.C., 1975) and Fernando Fajnzylber and Trinidad Martínez Tarragó, Las Empresas Transnacionales: Expansión a Nivel Mundial y Protección en la Industria Mexicana (Mexico, 1976).

22. Nacional Financiera is one of the most well-studied investment banks in a developing country. The discussion below, which will only highlight selected aspects of NAFIN's activities, draws on confidential interviews as well as on Calvin Blair, "Nacional Financiera: Entrepreneurship in a Mixed Economy," in Raymond Vernon, ed. Public Policy and Private Enterprise in Mexico (Cambridge, [Mass.], 1964); Jose Hernandez Delgado, The Contribution of Nacional Financiera to the Industrialization of Mexico (Mexico 1961); and Rosa Olivia Villa M., Nacional Financiera: Banco de Fomento del Desarrollo Económico de México (Mexico, 1976).

23. Rosa Olivia Villa M., ibid., p. 41.

24. Blair, pp. 213, 194.

25. See ibid., p. 232.

26. On these, see Mosk, Industrial Revolution in Mexico, pp. 163-6 (paper), and pp. 153-60 (cement); Rosa Olivia Villa M., pp. 43, 68 (paper); and Blair, p. 216 (cement).

27. The discussion of Altos Hornos and the steel industry more generally draws on interviews and on Norman Schneider, Government Competition in the Mexican Steel Industry (University of California, Davis: Institute of Government Affairs, 1967) and William E. Cole, Steel and Economic Growth in Mexico (Austin, [Tex.], 1967). 
28. Confidential interviews.

29. Glade, "Revolution and Economic Development," p. 93.

30. Victor Manuel Villasenor, Memorias de Un Hombre de Izquierda, vol. 2, "De Avila Camacho a Echeverría,"' (Mexico, 1976), p. 243. Villasenor was director of DINA from 1958 to 1970.

31. The state's takeover of Toyoda de Mexico, a textile machinery firm with Japanese technology, and capital, now called Siderúrgica Nacional (and, with DINA and CNCF, part of the Sahagún complex) followed a roughly similar course.

32. Including, for example, Aceros Esmaltados S.A. (a major stove manufacturer), Vehículos Automores Mexicanos S.A. (a joint venture in which American Motors is minority partner, manufacturing American Motors vehicles), Sosa Texcoco S.A. (a large chemical firm), and Manufacturera Mexicana de Partes de Automóviles S.A. (an important manufacturer of automobile parts). The acquisition by the government of Banco Internacional, now affiliated with NAFIN, followed similar motives.

33. On the sugar industry, see Samuel I. del Villar, "Depresión en la Industria Azucarera," Foro Internacional, 16, no. 4 (1976), 538-39.

34. For a more extensive discussion of the Mexicanization policy, see Bennett and Sharpe, "Controlling the Multinationals: The Ill Logic of Mexicanization," in Lawrence V. Gould and Harry Targ, Global Dominance and Dependence: Readings in Theory and Research (Brunswick, [Ohio], forthcoming).

35. A figure that includes 71 decentralized organisms, 351 firms with majority state participation, and 48 firms with minority state participation, but does not include an additional 47 " juntas federales de mejoras materiales"; Secretaría del Patrimonio Nacional, Directorio de Organismos Decentralizados y Empresas de Participación Estatal (Mexico, 1976).

36. In 1970, CFM participated in only fifteen enterprises, and mostly as a minority shareholder; in 1975, CFM was involved in thirty-eight ventures, many of them new investments of great magnitude, and often as majority shareholder. See Carlos Avila Martinez, "La Mineria en Mexico 1970-1975," in Secretaría del Patrimonio Nacional, Economía Publica: Soberania y Justicia Social (Mexico, 1976), p. 79.

37. The literature is voluminous, but see, for example, David Truman, The Governmental Process (New York, 1951).

38. See, for example, Ralph Miliband, The State in Capitalist Society (London, 1969).

39. See particularly Nicos Poulantzas, Political Power and Social Classes (London, 1973); and Louis Althusser, "Ideology and Ideological State Apparatuses," in Lenin and Philosophy and Other Essays (New York, 1971).

40. A good view of the bureaucratic politics approach can be obtained from Morton $\mathbf{H}$. Halperin and Arnold Kanter, Readings in American Foreign Policy: A Bureaucratic Perspective (Boston, 1977). Samuel Huntington's Political Order in Changing Societies (New Haven, 1968) also depicts the state as having orientation of its own, but the orientations he considers do not bear on state intervention into the economy.

41. See, for example, Miliband's critique in "Poulantzas and the Capitalist State," New Left Review, 82 (1973), 84.

42. Rosario Green, El Endeudamiento Publico Externo de Mexico, 1940-1973 (Mexico, 1976). 